\title{
Types of Medication-Assisted Treatment for Opioid Use Disorder in Turkey: The Perceptions of Inpatients about Treatment Success
}

\author{
Mehmet Aykut Erk and Sunay Firat $\bowtie$ \\ Çukurova University, Addiction and Forensic Sciences Institue, Adana, Turkey
}

\begin{abstract}
Objective The aim of this study was the following. When the different dynamics of agonist or antagonist treatments considered it is assumed that the eligible treatment to the individual may be maintained with high efficacy. Thus, we aimed to examine the difference between treatment methods, considering sociodemographics and positive perception for treatment success.

Methods The number of 136 individuals which their ages range between 19-50 and have been getting agonist (buprenorphine/naloxone) or antagonist (naltrexone) treatment because of opioid use disorder while resting in clinics have been evaluated to reveal the factors that may alter their perception about treatment and have been compared with sociodemographic variables and characteristics such as sociotropic and autonomic. Therefore, "Sociodemographic Data Evaluation Form," "Predictive Factors for The Addiction Treatment Success Scale," and "Sociotropy-Autonomy Scale" were used to assess the sociodemographic data, the perception towards factors which have been affected to the treatment and characteristics. The data of the individuals have been collected by the researcher via face-to-face interviews while patients were residential in the clinic.

Results According to results of our study, it has been detected that there are some differences in the perception of treatment success between individuals who have been getting agonist or antagonist treatments such as treatment method $(\mathrm{p}<0.05)$, treatment frequency $(\mathrm{p}<0.01)$ and parents' vital statuses $(\mathrm{p}<0.05)$.

Conclusion At the end of the study it has been understood that medical and social benefits after the selection of eligible treatment methods which is suitable for individual's perception and characteristics have to be considered.
\end{abstract}

Psychiatry Investig 2020;17(12):1182-1190

Key Words Opioid use disorder, Agonist, Antagonist, Implant, Perception, Success of treatment.

\section{INTRODUCTION}

Treatment options for opioid use disorder are constantly changing in line with the recent developments within this field. These treatment options can be generalized as detoxification or opioid withdrawal under the medical supervision, maintenance treatment by using other opioid agonists (methadone, levomethadyl acetate or buprenorphine) and other pharmacological treatment methods focused on abstinence and therapeutic communities (antagonist treatment). An individual's willingness to accept the treatment and choosing the appropri-

\section{Received: August 17, 2020 Accepted: September 22, 2020}

$\triangle$ Correspondence: Sunay Firat, PhD

Çukurova University, Addiction and Forensic Sciences Institue, Balcalı District, Cukurova University, Medicosocial Services Building, Block A, Balcalı, Sarıçam, Adana, 01250 Turkey

Tel: +90 32233860 84/22 86-16, E-mail: sunayfirat@gmail.com

(ac) This is an Open Access article distributed under the terms of the Creative Commons Attribution Non-Commercial License (https://creativecommons.org/licenses/bync/4.0) which permits unrestricted non-commercial use, distribution, and reproduction in any medium, provided the original work is properly cited. ate treatment method after that depends on his/her experiences, family relations, addiction severity. ${ }^{1}$

Oral naltrexone, a daily use medicine developed for the treatment of the opioid use disorder, has been approved for clinical use in the USA since the 1970s and has many different forms. Naltrexone has been listed in World Health Organization's treatment guidelines due to its positive effects such as the prevention of the harmful effects from the non-prescribed opioid use and relapses in the individuals presenting withdrawal symptoms. ${ }^{2}$ However, individuals' compliance problems with the treatment during clinical applications have raised doubts about the efficacy of the oral naltrexone and in 2010, FDA approved the use of the extended-release injectable naltrexone in relapse prevention programs (in conjunction with psychosocial programs) to benefit from its 30 days long blockade effects on opioid receptors from 1 dose. ${ }^{3}$ Another form of the naltrexone is the subcutaneous implant form. Naltrexone's implant form was developed in Australia ${ }^{4}$ and has been started to be used in standard clinical applications in Russia with Rus- 
sia's acquisition of its medical use permits.

Currently, two main methods are being used for the treatment of opioid use disorders in Turkey's Alcohol and Substance Addiction Research and Treatment Centres (ASARTC). These methods are: Using an agonist (buprenorphine) for withdrawal or replacement treatments or using an antagonist (naltrexone) for relapse treatment.

Personal, environmental, and sociodemographic factors can be considered as predictive factors on the success rate of addiction treatment. Individuals can be hesitant to accept the treatment for rapidly progressive and destructive disorders such as opioid use disorder. In that regard, choosing the proper treatment method in line with the individual's decisions about the treatment is very important. Therefore, maintaining the treatment's efficiency is only possible by considering the different dynamics of the agonist and antagonist treatments. Individuals' perceptions of treatment success, certain sociodemographic factors, and personality traits are regarded as the determiners for the treatment's efficiency.

This study was conducted to examine the personality traits of the individuals who have undergone agonist or antagonist treatments for opioid use disorder in an inpatient setting and their perceptions of addiction treatment success.

\section{METHODS}

\section{Subjects}

The study population was constituted of individuals that have been diagnosed with opioid use disorder by the DSM-5/ ICD-10 criteria and have undergone treatment for 3 months in Adana Dr. Ekrem Tok Psychiatric Hospital's ASARTC (Alcohol and Substance Addiction Rehabilitation and Treatment Center). 394 individuals aged between 19-56, were receiving treatment during the study date. Out of these 394 individuals, 68 individuals who have received antagonist treatment and 68 individuals who have received agonist treatment (136 in total) have accepted to participate in this study and constituted the sample group.

The study was approved by the Çukurova University Medicine Faculty Non-Invasive Ethical Clinical Researches Ethical Committee (Approval No. 2018-12, 78).

For data collection 3 methods were used: To collect the introductory information of the individuals who have received opioid use disorder treatment the "Sociodemographic Data Collection Form", to examine the perception of these individuals on the treatment the "Predictive Factors For The Addiction Treatment Success Scale (PFS)" and, to determine the personality traits of these individuals "Sociotrophy-Autonomy Scale (SAS)" was used. The researcher collected the data from the participants that received treatment for their opioid use disorder between the dates of September 2018-November 2018 in Adana Dr. Ekrem Tok Psychiatric Hospital's ASARTC. The Data were collected by face-to-face interviews with the participants, during their inpatient treatment in ASARTC 2 and 3 clinics. By taking the recommendations of the health professionals into account the individuals whose inpatient treatment recently started, the individuals that have presented withdrawal symptoms in the previous 1-3 days, and the individuals presenting insufficient cognitive function as a result of their buprenorphine treatment have been included in the study when they have achieved sobriety.

\section{Questionnaire}

\section{Sociodemographic Data Collection Form}

The "Sociodemographic Data Collection Form" that has been used in the study was semi-structured into two parts to determine the sociodemographic and clinical characteristics of the individuals. The first part of the form included demographic data about age, sex, marital status, occupation, etc. whereas the second part of the form included data about the age of substance use initiation, age at entering treatment and the legal issues individuals have experienced as a result of their substance use.

\section{Predictive Factors For The Addiction Treatment Success Scale (PFS)}

Predictive Factors For The Addiction Treatment Success Scale was constructed by Turan and Yargıç in 2010. ${ }^{5}$ After conducting a pilot study, Turan and Yargıç have identified several factors that can affect the success or failure of the treatment and observation programs and classified these factors under two groups. Social and Legal Factors Sub-scale, the first group, included 17 items, and the second group, Psychological Factors Sub-scale included 11 items. The scale is constructed in 4-point Likert type and has an internal consistency ratio of 0.879 for both sub-scales.

\section{Sociotropy-Autonomy Scale (SAS)}

SAS is a self-evaluation scale used to determine personality traits related to social dependency and social independency. ${ }^{6}$ The scale was introduced by Beck et al. ${ }^{7}$ in 1983, and was constructed in 5-point Likert type containing 60 items. It has two sub-scales of 30 items to measure sociotropic and autonomic personality traits. The scale's reliability score for the sociotropy is in the range of 0.89-0.94, and for autonomy it is in the range of $0.83-0.95 .^{8}$

\section{Statistical analyses}

Statistical analyses of the study were done with the pack- 
aged software named SPSS (IBM SPSS Statistics 22; IBM Corp., Armonk, NY, USA). Categorical variables of the descriptive statistics acquired by the study were summarized as numbers or percentages, whereas continuous variables were tabulated by considering mean values, standard deviation, median, minimum, and maximum values. In the comparison of the categorical variables between groups, chi-square test was used. To check whether the constant variables within the group distributed normally or not Kolmogorov Smirnov test was used. When comparing two independent groups, if the variables presented normal distribution Independent Samples $T$ test, if the variables distributed non normally Mann Whitney U test was used. When comparing more than two independent groups, in situations where the constant variables distributed normally One-Way ANOVA test was used whereas in case of non-normal distribution Kruskall-Wallis $\mathrm{H}$ test was used. The significance level was set at 0.05 for all the tests it was applied.

\section{RESULTS}

\section{Demographics}

The sociodemographic data of the participants are shown in Table 1. When the constant variables of this data analyzed, mean value and the standard deviation of the participants' ages were calculated as $27.57 \pm 5.34$ (min-max:19;56). For the age of opioid misuse initiation, mean value and the standard deviation were calculated as $17.53 \pm 4.25$ ( $\min -\max : 10 ; 32$ ).

When the participants were asked, "How many times did you receive inpatient treatment within the clinics?" 33 of them $(24.3 \%)$ said they have never received inpatient treatment, 30 of them $(22.1 \%)$ said they have received inpatient treatment once, 43 of them (31.6\%) said they have received inpatient treatment 2-4 times, 30 of them said (22.1\%) said they have received inpatient treatment more than 4 times. When the participants were asked, "Is your mother still alive?", 128 of them (94.1\%) said yes, and 8 of them (5.9\%) said no (Table 2).

Table 1. Sociodemographic continuous variables of patients

\begin{tabular}{lc}
\hline \multicolumn{1}{c}{ Variables } & $\overline{\mathrm{X}} \pm \mathrm{SD}(\mathrm{N}=136)$ \\
\hline Age & $27.57 \pm 5.34$ \\
Starting age & $17.53 \pm 4.25$ \\
Monthly income (Turkish Liras) & $3,034 \pm 3,305.48$ \\
Autonomy & $73.97 \pm 21.70$ \\
Sociotropy & $64.24 \pm 21.28$ \\
Social and legal factors & $47.42 \pm 7.98$ \\
Psychological factors & $31.67 \pm 5.75$ \\
PFS total & $79.09 \pm 12.83$
\end{tabular}

PFS: Predictive Factors for The Addiction Treatment Success Scale

\section{Group differences for perception of treatment success}

According to the data, mean value and standard deviation of the participants' autonomy scores are $73.97 \pm 21.70$, whereas the mean value and standard deviation for sociotropy are $64.24 \pm 21.28$.

Table 2. Sociodemographic categorical variables of patients

\begin{tabular}{|c|c|}
\hline Variables & $\mathrm{N}(\%), \mathrm{N}=136$ \\
\hline \multicolumn{2}{|l|}{ Age } \\
\hline $19-26$ & $68(50)$ \\
\hline 27 and above & $68(50)$ \\
\hline \multicolumn{2}{|l|}{ Starting age } \\
\hline 14 and below & $35(25.7)$ \\
\hline $15-16$ & $31(22.8)$ \\
\hline $17-19$ & $36(26.5)$ \\
\hline 19 and above & $34(25)$ \\
\hline \multicolumn{2}{|c|}{ Inpatient treatment frequency } \\
\hline None & $33(24.3)$ \\
\hline Once & $30(22.1)$ \\
\hline $2-4$ times & $43(31.6)$ \\
\hline Above 4 times & $30(22.1)$ \\
\hline \multicolumn{2}{|l|}{ Marital status } \\
\hline Married & $47(34.6)$ \\
\hline Single & $80(58.8)$ \\
\hline Divorced & $9(6.6)$ \\
\hline \multicolumn{2}{|l|}{ Number of children } \\
\hline None & $94(69.1)$ \\
\hline 1 child & $21(15.4)$ \\
\hline 2 children and above & $21(15.4)$ \\
\hline \multicolumn{2}{|l|}{ Educational status } \\
\hline Elementary & $24(17.6)$ \\
\hline Secondary & $48(35.3)$ \\
\hline High-school & $56(41.2)$ \\
\hline Collage & $8(5.9)$ \\
\hline \multicolumn{2}{|l|}{ Is mother alive? } \\
\hline Yes & $128(94.1)$ \\
\hline No & $8(5.9)$ \\
\hline \multicolumn{2}{|l|}{ Is father alive? } \\
\hline Yes & $110(80.9)$ \\
\hline No & $26(19.1)$ \\
\hline \multicolumn{2}{|l|}{ Beginning substance } \\
\hline Marijuana & $112(82.4)$ \\
\hline Heroin & $14(10.3)$ \\
\hline Others* & $10(7.4)$ \\
\hline \multicolumn{2}{|l|}{ Treatment history } \\
\hline None & $29(21.3)$ \\
\hline Exists & $107(78.7)$ \\
\hline \multicolumn{2}{|l|}{ Criminal record } \\
\hline None & $62(45.6)$ \\
\hline Exists & $74(54.4)$ \\
\hline
\end{tabular}

*inhalant, alcohol, stimulant 
When the individuals who are receiving the implant and sublingual treatments are compared in terms of psychological factor sub-scale point averages: For the participants receiving implant treatment, the mean value and the standard deviation of the psychological factor point were calculated as 32.65 \pm 6.08 whereas for the participants receiving the sublingual treatment it is calculated as $30.69 \pm 5.27$. This difference is statistically significant, according to Table 3 ( $\mathrm{p}=0.047$ ).

When the total PFS points for inpatient treatment times were compared, a statistically significant difference $(\mathrm{p}<0.001)$ were found between the PFS point averages of the "no history of inpatient treatment," "once," "2- 4 times" and, "more than 4 times" groups. A similar statistical significance $(\mathrm{p}<0.001)$ was found when the inpatient treatment times for the sublingual group compared.

\section{DISCUSSION}

During the study date, the number of female individuals receiving inpatient treatment within the clinics was not sufficient enough to constitute a statistical data. Therefore, only male individuals have been included in the study. When the related literature about the opioid use disorder treatment and the treatments of other substance addictions (alcohol, marijuana, etc.) was reviewed, it was seen that the males constituted a majority in treatment groups. In one study, $98.8 \%$ of the participants were male. ${ }^{9}$ This data is consistent with the maleto-female ratio (93.5-100\%) findings from the "Treatment and Probation Order" studies done in Turkey. ${ }^{10-12}$ The women that are using alcohol or other substances are negatively labeled in Turkish society; therefore, Turkish women tend not to use

Table 3. Individuals who are receiving the implant and sublingual treatments are compared in terms of factors sub-scale and total point averages

\begin{tabular}{|c|c|c|c|}
\hline & Implant $(\mathrm{N}=68)$ & Sublingual $(\mathrm{N}=68)$ & \\
\hline & $\begin{array}{c}\overline{\mathrm{X}} \pm \mathrm{SD} \\
\text { Median } \\
(\min -\mathrm{max})\end{array}$ & $\begin{array}{c}\overline{\mathrm{X}} \pm \mathrm{SD} \\
\text { Median } \\
(\min -\mathrm{max})\end{array}$ & $\mathrm{p}$ \\
\hline Autonomy & $\begin{array}{l}74.00 \pm 21.35 \\
77.50(22-120)\end{array}$ & $\begin{array}{l}73.94 \pm 22.20 \\
75(26-118)\end{array}$ & 0.987 \\
\hline Sociotropy & $\begin{array}{l}63.84 \pm 20.57 \\
66(22-113)\end{array}$ & $\begin{array}{l}64.65 \pm 22.12 \\
62.50(22-112)\end{array}$ & 0.826 \\
\hline $\begin{array}{l}\text { Social and legal } \\
\text { factors }\end{array}$ & $\begin{array}{l}48.47 \pm 8.53 \\
48(28-64)\end{array}$ & $\begin{array}{l}46.37 \pm 7.30 \\
47(30-61)\end{array}$ & 0.125 \\
\hline $\begin{array}{l}\text { Psychological } \\
\text { factors }\end{array}$ & $\begin{array}{l}32.65 \pm 6.08 \\
33.50(18-42)\end{array}$ & $\begin{array}{l}30.69 \pm 5.27 \\
30.50(20-40)\end{array}$ & 0.047 \\
\hline PFS total & $\begin{array}{l}81.12 \pm 14.04 \\
81(46-105)\end{array}$ & $\begin{array}{l}77.06 \pm 11.35 \\
75.50(57-98)\end{array}$ & 0.045 \\
\hline
\end{tabular}

PFS: Predictive Factors for The Addiction Treatment Success Scale them or use them in secret. This negative labeling can abstain women from using substances or prevent them from receiving treatment for their potential substance use disorders. ${ }^{13}$ Another possible reason for the difference between the male and female participant ratios could be the Turkish women's lower rates of risky behavior display compared to men, as a result of their relatively low social participation rates. ${ }^{14-16}$

When the "SAS" scores of the participants were analyzed, it was seen that the participants had relatively higher autonomy scores than sociotropy scores. This data suggests that the males present "autonomic" personality traits in terms of risky behavior display.

Participants displayed personality factors associated with substance use disorders such as novelty seeking, sensitivity to rewarding stimuli and reward-seeking behavior, and impulsive behavior. These findings are consistent with previous studies. ${ }^{17-19}$ Another study has shown that individuals who have decided to receive opioid use disorder treatment have more autonomic personality traits compared to sociotropic personality traits. ${ }^{20}$

Age of the individuals can be regarded as an important factor in the addiction treatment acceptance, treatment attendance, and treatment success. In this study, the average age of the participants was calculated as $27.57(\mathrm{SD}= \pm 5.34)$. These results are consistent with the related literature. In a similar study, ${ }^{9}$ the average age of the participants was calculated as $28.23(\mathrm{SD}= \pm 7.78)$, and in another study, $75.7 \%$ percent of the sample group was constituted of individuals aged $18-25 .{ }^{21}$ It is generally thought that most of the substance use disorders develop in adolescence or young adulthood, whereas individuals' opinions on treatment initiation or their treatment histories begin to form in adulthood. ${ }^{22,23}$

When the PFS scores of the participants that are receiving agonist or antagonist treatments are analyzed, it was seen that the antagonist group had scored higher in psychological subscale point averages and total PFS points compared to agonist group. Additionally, a statistically significant difference was found between these groups $(\mathrm{p}=0.047, \mathrm{p}=0.045)$. Antagonist treatment is different from traditional agonist maintenance treatments in terms of method of application and pre-treatment preparations. The aim of the antagonist treatment is to block the euphoria effect of the opioids, to prevent cravings and physical readdiction. Before administrating naltrexone, a sustained effect synthetic opioid antagonist, the individual must detoxify and abstain from the substance for a few days following detoxification. ${ }^{24}$

For the past 40 years, the most common and effective treatment options for substance addiction was maintenance treatments by using medical-use opioids instead of unprescribed opioids..$^{25}$ In the following years, it was found that pharmaco- 
therapeutic interventions were effective only in the one third of the individuals. ${ }^{26}$ Since the 2010s, agonists such as methadone have been started to be used in detoxification or maintenance treatments ${ }^{27}$ in Turkey, and they were considered as promising treatment methods. However, the individuals who wanted to keep their substance use disorder treatments a secret showed a lack of interest in methadone treatments and methadone treatments were regarded as insufficient. ${ }^{28,29}$ When some studies about the treatment attendance rates reviewed, it was seen that more than $50 \%$ of the patients had discontinued their buprenorphine treatment (another partial agonist) after 6 months. ${ }^{30-32}$ According to the findings of the two ethnographic and qualitative studies done with the individuals having opioid use disorders, it was found that the buprenorphine was abused to prevent withdrawal symptoms. ${ }^{32,33}$ In that regard, it can be said that most individuals perceive agonist treatments as a replacement for their addiction rather than a treatment. ${ }^{34}$

As another method, naltrexone's implant form has been started to used in antagonist treatments in place of placebos since mid 90s and showed effective results in heroin abstinence and prevention of relapse episodes.$^{35}$ Consistent effects of narcotic antagonists such as Naloxone and naltrexone on opioid and alcohol use disorders, provided a new alternative method for addiction treatment. ${ }^{36,37}$ Following these developments, countries that have provided only detoxification treatments such as Russia have started to implement antagonist treatments by totally discarding agonist treatments. ${ }^{38}$ In a study done in Ukraine, a country providing both agonist and antagonist treatments, it was found that the individuals who are using heroin intravenously have often preferred naltrexone treatments. ${ }^{39,40}$

Compared to agonist treatments, antagonist treatments cause a controlled withdrawal in treatment initiation without any induction process. Individuals treatment readiness levels and their fear of withdrawal can affect their perception of antagonist treatment. In that regard, it is thought that the individuals show hesitancy while receiving antagonist treatments compared to agonist treatments. ${ }^{41-43}$ However, by receiving antagonist treatments, implant naltrexone or depot naltrexone treatments, in particular, individuals can continue their daily lives as they don't have to get frequent inpatient treatments and this might affect their social interactions positively. With implant treatment, individuals can spend their time on returning to social life since they don't have to pay frequent visits to treatment clinics. ${ }^{44}$ Subcutaneous implants do not leave clearly visible marks on individuals' bodies, and this could positively affect individuals' perception of treatment success. ${ }^{45,46}$ Additionally, individuals might forget or refuse to take their medicines (oral naltrexone, methadone, etc.) during their inpatient or outpatient treatments in the clinic. However, naltrexone's implant form is quite effective in overcoming the problems of treatment compliance, forgetfulness, and agonist intake overdose. ${ }^{47}$ Naltrexone eliminates the risk of agonist misuse; therefore, it is preferred in treatments. ${ }^{48}$

According to this study's findings, another reason for the statistically significant difference between the naltrexone implant group and the suboxone group could be the strong quitting motivation of the naltrexone implant group. When related literature is reviewed, it was found that higher compliance rates provided better results in agonist treatment. ${ }^{46,49}$

Naltrexone implants benefits such as elimination of agonist misuse risk and their effectiveness in treatment have been proved by several studies. ${ }^{40,50-52}$ Implant treatments can be considered more successful than agonist treatments since it provides long remission periods while having shorter treatment episodes. ${ }^{53-55}$

Naltrexone treatments' higher efficiency in comparison to traditional treatment methods is well documented by most of the clinical studies in the literature. ${ }^{50,56-58}$ Additionally, it was found that naltrexone implants are more effective in the prevention of opioid misuse compared to traditional agonist treatments (oral naltrexone) and placebo. ${ }^{59}$

When the participants who are receiving agonist or antagonist treatments are compared by the number of times they have received inpatient treatment, it was found that the individuals who have received fewer inpatient treatments had higher and statistically significant total score in PFS* (and in all Sub-scales) in comparison to individuals that had inpatient treatments more than 2-4 times (Table 4).

Considering the addictive and destructive potential of the opioid use disorder it is normal for an individual to receive inpatient treatments in the clinics. In a study, the average value for the inpatient treatment times was calculated as 1.7. ${ }^{60}$ In the study of Yalnız et al., ${ }^{61} 77.6 \%$ of the Turkish heroin addicts living in Germany have reported that they have received inpatient treatment before and $28.6 \%$ of the addicts have reported they have received inpatient treatment more than 4 times. Substance use disorders, by their nature, is a quite difficult condition to overcome, and the individuals that try to quit their substance abuse may fail many times. This situation causes an increase in treatment frequency. ${ }^{60}$ Most individuals are highly motivated to pursue their addiction treatments, but long withdrawal periods may negatively affect their compliance with the treatment. ${ }^{62,63}$ The findings of this study suggest that individuals with fewer inpatient treatment times have a more positive perception of treatment success. This positive perception possibly results from the implant treatments' long-term effects such as lower frequency of withdrawal, relapse, and lapse. When the related literature was reviewed, it was found that most of the individuals with no treatment history have 
Table 4. Individuals who are receiving the implant and sublingual treatments are compared in terms of factors sub-scale and total point averages regarding the question inpatient treatment frequency

\begin{tabular}{|c|c|c|c|}
\hline \multirow[b]{2}{*}{$\begin{array}{l}\text { Inpatient } \\
\text { treatment } \\
\text { frequency }\end{array}$} & Implant $(\mathrm{N}=68)$ & Sublingual (N=68) & \multirow[b]{2}{*}{$\mathrm{p}$} \\
\hline & $\begin{array}{c}\overline{\mathrm{X}} \pm \mathrm{SD} \\
\text { Median } \\
(\mathrm{min}-\mathrm{max})\end{array}$ & $\begin{array}{c}\overline{\mathrm{X}} \pm \mathrm{SD} \\
\text { Median } \\
(\mathrm{min}-\mathrm{max})\end{array}$ & \\
\hline \multicolumn{4}{|l|}{ Autonomy } \\
\hline None & $\begin{array}{l}79.26 \pm 18.08 \\
78(48-116)\end{array}$ & $\begin{array}{l}74.64 \pm 14.39 \\
72(58-100)\end{array}$ & 0.436 \\
\hline Once & $\begin{array}{l}75.44 \pm 26.12 \\
68\left(45^{-120)}\right.\end{array}$ & $\begin{array}{l}68.38 \pm 27.30 \\
65(32-118)\end{array}$ & 0.516 \\
\hline 2-4 times & $\begin{array}{l}69.13 \pm 23.35 \\
77(22-108)\end{array}$ & $\begin{array}{l}72 \pm 24.36 \\
75(26-110)\end{array}$ & 0.696 \\
\hline Above 4 times & $\begin{array}{l}74.25 \pm 19.25 \\
76.50(41-113)\end{array}$ & $\begin{array}{l}84.21 \pm 13.94 \\
85(61-106)\end{array}$ & 0.120 \\
\hline $\mathrm{p}$ & 0.494 & 0.216 & \\
\hline \multicolumn{4}{|l|}{ Sociotropy } \\
\hline None & $\begin{array}{l}63.79 \pm 17.25 \\
70(33-83)\end{array}$ & $\begin{array}{l}62.86 \pm 15.30 \\
57(38-89)\end{array}$ & 0.873 \\
\hline Once & $\begin{array}{l}64.33 \pm 32.38 \\
62(22-113)\end{array}$ & $\begin{array}{l}63.24 \pm 26.29 \\
67(22-112)\end{array}$ & 0.923 \\
\hline 2-4 times & $\begin{array}{l}60.71 \pm 19.29 \\
64.50(22-94)\end{array}$ & $\begin{array}{l}65.47 \pm 25.05 \\
61(22-106)\end{array}$ & 0.485 \\
\hline Above 4 times & $\begin{array}{l}68.31 \pm 19.13 \\
69.50(29-103)\end{array}$ & $\begin{array}{l}67.43 \pm 18.40 \\
65.50(36-105)\end{array}$ & 0.899 \\
\hline $\mathrm{p}$ & 0.734 & 0.938 & \\
\hline \multicolumn{4}{|c|}{ Social and legal factors } \\
\hline None & $\begin{array}{l}54.32 \pm 6.07 \\
56(44-62)\end{array}$ & $\begin{array}{l}52 \pm 5.44 \\
52.50(42-60)\end{array}$ & 0.267 \\
\hline Once & $\begin{array}{l}55.11 \pm 8.19 \\
57(41-64)\end{array}$ & $\begin{array}{l}49.81 \pm 5.75 \\
49(40-61)\end{array}$ & 0.039 \\
\hline 2-4 times & $\begin{array}{l}45.21 \pm 7.83 \\
48(28-56)\end{array}$ & $\begin{array}{l}43.11 \pm 6.02 \\
43(32-55)\end{array}$ & 0.340 \\
\hline Above 4 times & $\begin{array}{l}42.69 \pm 5.37 \\
43.50(33-52)\end{array}$ & $\begin{array}{l}40 \pm 5.63 \\
40.50(30-48)\end{array}$ & 0.192 \\
\hline $\mathrm{p}$ & $<0.001$ & $<0.001$ & \\
\hline \multicolumn{4}{|c|}{ Psychological factors } \\
\hline None & $\begin{array}{l}36.32 \pm 3.28 \\
37(29-41)\end{array}$ & $\begin{array}{l}34.14 \pm 4.73 \\
35.50(24-40)\end{array}$ & 0.129 \\
\hline Once & $\begin{array}{l}33.27 \pm 5.84 \\
33(20-41)\end{array}$ & $\begin{array}{l}33.48 \pm 3.98 \\
34(27-40)\end{array}$ & 0.069 \\
\hline 2-4 times & $\begin{array}{l}30.96 \pm 6.50 \\
33(18-41)\end{array}$ & $\begin{array}{l}28.16 \pm 4.37 \\
28(21-37)\end{array}$ & 0.115 \\
\hline Above 4 times & $\begin{array}{l}28.75 \pm 5.50 \\
29(20-41)\end{array}$ & $\begin{array}{l}26.50 \pm 4.01 \\
26(20-34)\end{array}$ & 0.217 \\
\hline $\mathrm{p}$ & $<0.001$ & $<0.001$ & \\
\hline
\end{tabular}

Table 4. Individuals who are receiving the implant and sublingual treatments are compared in terms of factors sub-scale and total point averages regarding the question inpatient treatment frequency (continued)

\begin{tabular}{|c|c|c|c|}
\hline \multirow[b]{2}{*}{$\begin{array}{l}\text { Inpatient } \\
\text { treatment } \\
\text { frequency }\end{array}$} & Implant $(\mathrm{N}=68)$ & Sublingual $(\mathrm{N}=68)$ & \multirow[b]{2}{*}{$\mathrm{p}$} \\
\hline & $\begin{array}{c}\overline{\mathrm{X}} \pm \mathrm{SD} \\
\text { Median } \\
(\min -\mathrm{max})\end{array}$ & $\begin{array}{c}\overline{\mathrm{X}} \pm \mathrm{SD} \\
\text { Median } \\
(\mathrm{min}-\mathrm{max})\end{array}$ & \\
\hline \multicolumn{4}{|l|}{ PFS total } \\
\hline None & $\begin{array}{l}90.63 \pm 8.93 \\
93(73-103)\end{array}$ & $\begin{array}{l}86.14 \pm 8.12 \\
89(72-98)\end{array}$ & 0,149 \\
\hline Once & $\begin{array}{l}91.44 \pm 12.51 \\
95(69-105)\end{array}$ & $\begin{array}{l}83.29 \pm 8.21 \\
86(67-94)\end{array}$ & 0,026 \\
\hline $2-4$ times & $\begin{array}{l}76.17 \pm 13.56 \\
80(46-97)\end{array}$ & $\begin{array}{l}71.26 \pm 8.79 \\
69(59-87)\end{array}$ & 0,180 \\
\hline Above 4 times & $\begin{array}{l}71.44 \pm 10.07 \\
71(53-86)\end{array}$ & $\begin{array}{l}66.50 \pm 8.15 \\
65.50(57-82)\end{array}$ & 0,155 \\
\hline $\mathrm{p}$ & $<0.001$ & $<0.001$ & \\
\hline
\end{tabular}

PFS: Predictive Factors for The Addiction Treatment Success Scale

started their rehabilitation process with implant treatments. ${ }^{64}$ However, as the inpatient treatment frequency increases individuals develop negative attitudes and perceptions toward treatment success, and this could cause them to score lower in PFS scale. As the treatment frequency increase, individuals get into a state of learned helplessness, lose their motivation, and fail to meet treatment requirements. ${ }^{65,66}$

When the participants have been compared in regards to their mothers' vital status, it was found that the participants who are receiving antagonist treatment and have their mothers alive had scored higher in PFS total points and sub-scales averages. This difference is statistically significant (Table 5). According to Reece's ${ }^{67}$ study, working at a job prior to implant treatment and social support can affect the treatment outcome. Antagonist implant treatment is a relatively new treatment option in Turkey; however, it is being regarded as a promising development by most substance abusers and their families. This positive impression may cause encourage families to refer their relatives to implant treatments. ${ }^{68,69}$ In some cases, pressure from mothers and friends can affect the treatment process. Verbal persuasion can cause individuals to develop a positive perception of treatment. ${ }^{70,71}$

Short term harms of the opioid use disorder can be noticed by the parents earlier than the individual, and this might motivate parents to search for a treatment for their child. ${ }^{72}$ Parents' economic and emotional support can positively affect the individuals perception of treatment success. ${ }^{73}$ In another qualitative study, it was found that the individuals developed a positive perception toward treatment and accepted the treatment after seeing their parents' sorrow. ${ }^{74}$ Additionally, family and 
Table 5. Individuals who are receiving the implant and sublingual treatments are compared in terms of factors sub-scale and total point averages regarding the question "Is your mother still alive?"

\begin{tabular}{|c|c|c|c|}
\hline \multirow[b]{2}{*}{$\begin{array}{l}\text { "Is your mother } \\
\text { still alive?" }\end{array}$} & Implant $(\mathrm{N}=68)$ & Sublingual $(\mathrm{N}=68)$ & \multirow[b]{2}{*}{$\mathrm{p}$} \\
\hline & $\begin{array}{c}\overline{\mathrm{X}} \pm \mathrm{SD} \\
\text { Median } \\
(\mathrm{min}-\mathrm{max})\end{array}$ & $\begin{array}{c}\overline{\mathrm{X}} \pm \mathrm{SD} \\
\text { Median } \\
(\mathrm{min}-\mathrm{max})\end{array}$ & \\
\hline \multicolumn{4}{|l|}{ Autonomy } \\
\hline Yes & $\begin{array}{l}74.50 \pm 20.56 \\
77.50(25-120)\end{array}$ & $\begin{array}{l}73.74 \pm 21.96 \\
75(26-110)\end{array}$ & 0.840 \\
\hline No & $\begin{array}{l}57.50 \pm 50.20 \\
57.50(22-93)\end{array}$ & $\begin{array}{l}76 \pm 26.69 \\
74.50(40-118)\end{array}$ & 0.503 \\
\hline $\mathrm{p}$ & 0.716 & 0.814 & \\
\hline \multicolumn{4}{|l|}{ Sociotropy } \\
\hline Yes & $\begin{array}{l}64.38 \pm 20.37 \\
67.50(22-113)\end{array}$ & $\begin{array}{l}46 \pm 26.87 \\
46(27-65)\end{array}$ & 0.884 \\
\hline No & $\begin{array}{l}63.84 \pm 21.35 \\
61.50(22-106)\end{array}$ & $\begin{array}{l}73 \pm 30.01 \\
79(27-112)\end{array}$ & 0.305 \\
\hline $\mathrm{p}$ & 0.216 & 0.336 & \\
\hline \multicolumn{4}{|c|}{ Social and legal factors } \\
\hline Yes & $\begin{array}{l}48.62 \pm 8.49 \\
48(28-64)\end{array}$ & $\begin{array}{l}46.24 \pm 7.24 \\
47(30-61)\end{array}$ & 0.092 \\
\hline No & $\begin{array}{l}43.50 \pm 12.02 \\
43.50(35-52)\end{array}$ & $\begin{array}{l}47.67 \pm 8.54 \\
46(39-58)\end{array}$ & 0.600 \\
\hline $\mathrm{p}$ & 0.407 & 0.652 & \\
\hline \multicolumn{4}{|c|}{ Psychological factors } \\
\hline Yes & $\begin{array}{l}32.81 \pm 5.93 \\
33.50(18-42)\end{array}$ & $\begin{array}{l}30.71 \pm 5.09 \\
30.50(20-40)\end{array}$ & 0.033 \\
\hline No & $\begin{array}{l}27 \pm 11.31 \\
27(19-35)\end{array}$ & $\begin{array}{l}30.50 \pm 7.42 \\
30.50(22-40)\end{array}$ & 0.620 \\
\hline $\mathrm{p}$ & 0.772 & 0.283 & \\
\hline \multicolumn{4}{|l|}{ PFS total } \\
\hline Yes & $\begin{array}{l}81.44 \pm 13.83 \\
81(46-105)\end{array}$ & $\begin{array}{l}76.95 \pm 11.24 \\
77.50(57-98)\end{array}$ & 0.047 \\
\hline No & $\begin{array}{l}70.50 \pm 23.33 \\
70.50(54-87)\end{array}$ & $\begin{array}{l}78.17 \pm 13.46 \\
78(62-93)\end{array}$ & 0.568 \\
\hline $\mathrm{p}$ & 0.281 & 0.804 & \\
\hline
\end{tabular}

PFS: Predictive Factors for The Addiction Treatment Success Scale

friends have a quite an important role in supporting the individuals through the possible negative experiences they can have during their treatment. ${ }^{68,75}$

When the individuals who have undergone agonist or antagonist treatments for opioid use disorder in an inpatient setting were reviewed with regards to factors for treatment success and sociotropic-autonomic personality traits; it was seen that their perceptions on treatment success were affected by the treatment method, treatment frequency, parents' vital statuses while individuals' monthly income did not make a significant difference.
By taking these findings into account, treatment methods can be altered regarding the individuals' personality traits and motivation. It is hoped that the findings of this study would be helpful in solving the problems related to treatment acceptance, treatment compliance, and recovery expectancies. Informing the individuals about the processes of these two treatment methods before initiating treatment can be helpful for them to choose the right treatment method for themselves and comply with their treatments. Affording an implant treatment can be difficult for some individuals. Aid agencies and social security institutions can have an effective role in the protection of the individuals and society by supporting these individuals in need.

There are some limitations to this study. One of them is the exclusion of women from this study. Another limitation is the relatively small size of the sample group. More people could be included in this study if it had a longer time period. Another limitation of this study is the presence of withdrawal symptoms on the individuals that are having inpatient treatments in ASARTC clinics and discontinuation of treatment. This limitation could affect the size of the sample group and participation rates.

\section{Acknowledgments}

The authors thank all the study participants in Adana for their participation and efforts. The author(s) disclosed receipt of the following financial support for the research, authorship, and/or publication of this article: This work was supported by the Trust (10830-TYL-2018-10830). The current data were also presented at the 3rd International meeting of the Mediterranean Symposium in Mersin in Turkey, October 31-November 2, 2019.

The authors completed their work in compliance with confidentiality standards.

\section{Conflicts of Interest}

The authors have no potential conflicts of interest to disclose.

\section{Author Contributions}

Conceptualization: Sunay Firat. Data curation: Mehmet Aykut Erk. Formal analysis: Mehmet Aykut Erk. Funding acquisition: Sunay Firat. Investigation: Mehmet Aykut Erk, Sunay Firat. Methodology: Mehmet Aykut Erk, Sunay Firat. Project administration: Sunay Firat. Resources: Sunay Firat. Software: Mehmet Aykut Erk. Supervision: Sunay Firat. Validation: Mehmet Aykut Erk. Visualization: Mehmet Aykut Erk. Writing_original draft: Mehmet Aykut Erk. Writing_review \& editing: Sunay Firat.

\section{ORCID iDs}

Mehmet Aykut Erk https://orcid.org/0000-0002-4362-2729

Sunay Firat https://orcid.org/0000-0002-9960-0836

\section{REFERENCES}

1. Dilbaz, N. Opioid Addiction, in Madde bağımlllığı tanı ve tedavi kılavuzu el kitabı. Available at: https://sbu.saglik.gov.tr/Ekutuphane/kitaplar/ maddebagimliligi.pdf. Accessed January 17, 2019.

2. World Health Organization. Guidelines for the Psychosocially Assisted Pharmacological Treatment of Opioid Dependence. Available at: https://www.ncbi.nlm.nih.gov/books/NBK143185/pdf/Bookshelf_ NBK143185.pdf. Accessed December 11, 2018. 
3. Bisaga A, Mannelli P, Sullivan MA, Vosburg SK, Compton P, Woody GE, et al. Antagonists in the medical management of opioid use disorders: historical and existing treatment strategies. Am J Addict 2018; 27:177-187.

4. Hulse GK, Arnold-Reed DE, O’Neil G, Chan CT, Hansson R, O'Neil P. Blood naltrexone and 6-b-naltrexol levels following naltrexone implant: comparing two naltrexone implants. Addict Biol 2004;9:59-65.

5. Turan R. Madde Kullanımı Nedeniyle Denetimli Serbestlik ve Tedavi Tedbirine Hükmolan Kişilerin Tedaviyi Başarıyla Tamamlamalarını Öngören Etkenlerin İrdelenmesi. Doctoral Thesis. İstanbul: İstanbul University Institute of Forensic Sciences, 2010.

6. Beck AT, Epstein N, Harrison RP, Emery G. Development of the Sociotropy-Autonomy Scale: A measure of personality factors in psychopathology. Philadelphia: University of Pennsylvania; 1983.

7. Beck AT, Epstein N, Harrison R. Cognitions, attitudes and personality dimensions in depression. Br J Cogn Psychother 1983;1:1-16.

8. Şahin NH, Ulusoy M, Şahin N. Exploring the sociotropy-autonomy dimensions in a sample of Turkish psychiatric inpatients. J Clin Psychol 1993;49:751-763.

9. Hısım Ö. Denetimli Serbestlik Kapsamında Tedavideki Opiyat Kullanım Bozukluğu Olan Hastaların Opiyat İdame Tedavisine Uyumu ve Etki Eden Faktörler. MD Thesis. İstanbul: Bakırköy Prof. Dr. Mazhar Osman Ruh Sağlığı ve Sinir Hastalıkları Eğitim ve Araştırma Hastanesi Psikiyatri Kliniği; 2016.

10. Petin B. Denetimli Serbestlik Kapsamında Madde Bağımlılığı İçin Tedaviye Yönlendirilen Olguların Algıladıkları Aile Desteğinin Tedaviye Etkisi ve Ailelerinde Psikiyatrik Tanı Varlığı. M.D Thesis. İzmir: Psychiatry Department, Ege University Faculty of Medicine; 2014.

11. Düztaş SK. Personality Profiles of the Individuals Referred to Probation Institutions and Measuring Addiction Severity. Social Sciences Master Thesis. İstanbul: Istanbul University Institute of Forensic Sciences, Social Sciences Department; 2011.

12. Bahçeci B, Çelik FH, Kandemir G, Güveli H, Polat S, Hocaoğlu Ç. Evaluation of the patients applied by probation referring to a training and reasearch hospital in the eastern black sea region. J Forens Med 2014; 28:1-9.

13. Altıntoprak E. Kadınlar ve Bağımlılık. VII. Ulusal Alkol ve Madde Bağımlılığı Kongresi/VII. Belek-Antalya: National Alcohol and Substance Addiction Congress Abstracts Book; 2011.

14. İnce A, Doğruer Z, Türkçapar HM. Erken ve geç başlangıçlı erkek alkol bağımlılarında sosyodemografik, klinik ve psikopatolojik özelliklerin karşılaştırılması. Klinik Psikiyatri Dergisi 2002;5:82-91.

15. Asan Ö, Tikır B, Okay İT, Göka E. Bir AMATEM birimine başvuran alkol ve madde kullanım bozukluğu olan hastaların sosyodemografik ve klinik özellikleri. Bağımlılık Dergisi 2015;16:1-8.

16. Vogel DL, Bitman RL, Hammer JH, Wade NG. Is stigma internalized? the longitudinal impact of public stigma on self-stigma. J Couns Psychol 2013;60:311-323.

17. Cloninger CR, Svrakic DM, Przybeck TR. A psychobiological model of temperament and character. Arch Gen Psychiatry 1993;50:975-990.

18. Hansenne M, Pinto E, Pitchot W, Reggers J, Scantamburlo G, Moor M, Ansseau M. Further evidence on the relationship between dopamine and novelty seeking: a neuroendocrine study. Pers Individ Dif 2002; 33:967-977.

19. Köse S. A Psychobiological model of temperament and character: TCI. Yeni Sempozyum 2003;41:86-97.

20. Notley C, Holland R, Maskrey V, Nagar J, Kouimtsidis C. Regaining control: the patient experience of supervised compared with unsupervised consumption in opiate substitution treatment. Drug Alcohol Rev 2014;33:64-70.

21. Bayrak B. Effect of Group Counseling Applied to Individuals with Opioid Use Disorder and to Their Relatives on Individuals' Remission Period and Perception of Social Support and Individuals' and Their Relatives' Self-Efficacy and Hopelessness Level. Doctoral thesis. Ankara: Hacettepe University Medical Sciences Institute; 2018.
22. Karaca E, Sonmez B, Sipka H, Vardar E. Evaluation of dependency dimensions and individual characteristics according to the substance used. 50th National Congress of Psychiatry. Turk Psikiyatri Derg 2014; 25:32-35.

23. Saatcioglu O, Evren EC, Cakmak D. Evaluation of inpatient cases with alcohol and drug use between [year]s of 1998 and 2002. J Depend 2003;4:109-117.

24. Akvardarlar Y, Arıkan Z, Berkman K, Dilbaz N, Oral G, Uluğ B, et al. Guidelines for The Diagnosis and Treatment of Substance Addictions. Available at: https://sbu.saglik.gov.tr/Ekutuphane/Yayin/461. Accessed March 10, 2019.

25. Tiihonen J, Krupitsky E, Verbitskaya E, Blokhina E, Mamontova O, Föhr J, et al. Naltrexone implant for the treatment of polydrug dependence: a randomized controlled trial. Am J Psychiatry 2012;169:531536.

26. Luty J. Treatment preferences of opiate-dependent patients. Psychol Bull 2004;28:47-50.

27. Republic of Turkey Ministry of Health Directorate General of Medicine and Pharmacy. Available at: http://e-kutuphane.teb.org.tr/pdf/eczaciodasiyayinlari/farmaktu_eki-ara09/9.pdf. Accessed February 19, 2019.

28. Woods J. Methadone advocacy: the voice of the patient. Mt Sinai J Med 2001;68:75-78.

29. Joseph H, Stancliff S, Langrod J. Methadone maintenance treatment (MMT): a review of historical and clinical issues. Mt Sinai J Med 2000; 67:347-364.

30. Lee JD, Grossman E, DiRocco D, Gourevitch MN. Home buprenorphine/naloxone induction in primary care. J Gen Intern Med 2009;24: 226-232.

31. Timko C, Schultz NR, Cucciare MA, Vittorio L, Garrison-Diehn C. Retention in medication-assisted treatment for opiate dependence: a systematic review. J Addict Dis 2016;35:22-35.

32. Mitchell GS, Kelly SM, Brown BS, Reisinger HS, Peterson JA, Ruhf A, et al. Uses of diverted methadone and buprenorphine by opioid-addicted individuals in Baltimore, Maryland. Am J Addict 2009;18:346355.

33. Monte AA, Mandell T, Wilford BB, Tennyson J, Boyer EW. Diversion of buprenorphine/naloxone coformulated tablets in a region with high prescribing prevalence. J Addict Dis 2009;28:226-231.

34. Polonsky M, Rozanova J, Azbel L, Bachireddy C, Izenberg J, Kiriazova $\mathrm{T}$, et al. Attitudes toward addiction, methadone treatment, and recovery among HIV-infected Ukrainian prisoners who inject drugs: incarceration effects and exploration of mediators. AIDS Behav 2016;20: 2950-2960.

35. Kunøe N, Lobmaier P, Vederhus JK, Hjerkinn B, Hegstad S, Gossop M, et al. Retention in naltrexone implant treatment for opioid dependence. Drug Alcohol Depend 2010;111:166-169.

36. Treatment Improvement Protocol (TIP) Series, No 49. Available at: https://www.ncbi.nlm.nih.gov/books/NBK64041/ Accessed April 13, 2019.

37. Hubbell C, Czirr S, Hunter G, Beaman C, LeCann N, Reid L. Consumption of ethanol solution is potentiated by morphine and attenuated by naloxone persistently across repeated daily administrations. Alcohol 1986;3:39-54.

38. Krupitsky E, Zvartau E, Blokhina E, Verbitskaya E, Wahlgren V, TsoyPodosenin M, et al. Randomized trial of longacting sustained-release naltrexone implant vs oral naltrexone or placebo for preventing relapse to opioid dependence. Arch Gen Psychiatry 2012;69:973-981.

39. Marcus R, Makarenko I, Mazhnaya A, Zelenev A, Polonsky M, Madden L, et al. Patient preferences and extended-release naltrexone: a new opportunity to treat opioid use disorders in Ukraine. Drug Alcohol Depend 2017;179:213-219.

40. Krupitsky E, Zvartau E, Woody G. Use of naltrexone to treat opioid addiction in a country in which meethadone and buprenorphine are not available. Curr Psychiatry Rep 2010;12:448-453. 
41. Ahamad K, Milloy MJ, Nguyen P, Uhlmann S, Johnson C, Korthuis TP, et al. Factors associated with willingness to take extended release naltrexone among injection drug users. Addict Sci Clin Pract 2015;10:1-6.

42. Friedmann PD, Wilson D, Hoskinson R, Poshkus, MJr, Clarke JG. Initiation of extended release naltrexone (XR-NTX) for opioid use disorder prior to release from prison. J Subst Abuse Treat 2018;85:45-48.

43. Marcus R, Bojko MJ, Mazhnaya A, Makarenko I, Filippovych S, Dvoriak $S$, et al. A qualitative assessment of attitudes about and preferences for extended-release naltrexone, a new pharmacotherapy to treat opioid use disorders in Ukraine. J Subst Abuse Treat 2018;86:86-93.

44. Neale J, Tompkins CN, McDonald R, Strang J. Implants and depot injections for treating opioid dependence: qualitative study of people who use or have used heroin. Drug Alcohol Depend 2018;189:1-7.

45. Nettleton S, Neale J, Pickering L. I just want to be normal": an analysis of discourses of normality among recovering heroin users. Health 2013;17:174-190.

46. Gold CG, Cullen DJ, Gonzales S, Houtmeyers D, Dwyer MJ. Rapid opioid detoxification during general anesthesia: a review of 20 patients. Anesthesiology 1999;91:1639-1647.

47. Itzoe M, Guarnieri M. New developments in managing opioid addiction: impact of a subdermal buprenorphine implant. Drug Des Devel Ther 2017;11:1429-1437.

48. Carter JA, Dammerman R, Ling W, Frost M. Modelling the effectiveness of subdermally implanted buprenorphine, injectable naltrexone, and sublingual buprenorphine for clinically stable adults with opioid dependence. Can J Addict 2016;7:26.

49. Blanco-Gandía MC, Rodriguez-Arias M. Pharmacological treatments for opiate and alcohol addiction: a historical perspective of the last 50 years. Eur J Pharmacol 2018;836:89-101.

50. Comer SD, Sullivan MA, Yu E, Rothenberg JL, Kleber HD, Kampman $\mathrm{K}$, et al. Injectable, sustained-release naltrexone for the treatment of opioid dependence: A randomized, placebo-controlled trial. Arch Gen Psychiatry 2006;63:210-218.

51. Krupitsky E, Nunes EV, Ling W, Illeperuma A, Gastfriend DR, Silverman BL. Injectable extended-release naltrexone for opioid dependence: a double-blind, placebo-controlled, multicentre randomised trial. Lancet 2011;377:1506-1513.

52. Hulse GK, Morris N, Arnold-Reed D, Tait RJ. Improving clinical outcomes in treating heroin dependence: randomized controlled trial of oral or implant naltrexone. Arch Gen Psychiatry 2009;66:1108-1115.

53. Burns L, Gisev N, Larney S, Dobbins T, Gibson A, Kimber J, et al. A longitudinal comparison of retention in buprenorphine and methadone treatment for opioid dependence in New South Wales, Australia. Addiction 2015;110:646-655.

54. Teesson M, Marel C, Darke S, Ross J, Slade T, Burns L, et al. Long-term mortality, remission, criminality and psychiatric comorbidity of heroin dependence: 11-year findings from the Australian Treatment Outcome Study. Addiction 2015;110:986-993.

55. Xia Y, Seaman S, Hickman M, Macleod J, Robertson R, Copeland L, et al. Factors affecting repeated cessations of injecting drug use and relapses during the entire injecting career among the Edinburgh Addiction Cohort. Drug Alcohol Depend 2015;151:76-83.

56. Lee JD, Friedmann PD, Kinlock TW, Nunes EV, Boney TY, Hoskinson RA, et al. Extended release naltrexone to prevent opioid relapse in criminal justice offenders. N Engl J Med 2016;374:1232-1242.

57. Krupitsky E, Blokhina E, Zvartau E, Woody G. Antagonist treatment for opioid dependence: promise and hurdles. Curr Treat Options Psychiatry 2017;4:221-230.

58. Lee JD, Nunes EV, Bailey GL, Brigham GS, Cohen AJ, Fishman M, et al. NIDA Clinical Trials Network CTN-0051, extended-release naltrex- one vs. buprenorphine for opioid treatment (X: BOT): study design and rationale. Contemp Clin Trials 2016;50:253-264.

59. Larney S, Gowing L, Mattick RP, Farrell M, Hall W, Degenhardt L. A systematic review and meta-analysis of naltrexone implants for the treatment of opioid dependence. Drug Alcohol Rev 2014;33:115-128.

60. Yıldız M. Opiyat Bağımlılarının Sosyodemografik ve Kişilik Özelliklerinin Göç ile İlişkilendirilmesi, MD Thesis. Antalya: Akdeniz University Faculty of Medicine Department of Psychiatry Dali; 2014.

61. Yalnız Ö, Pektaş Ö, Şahin E, Kalyoncu AÖ, Mırsal H, Beyazyürek M. Almanyảda Yaşayan Türk Eroin Bağımlılarının Tedavi Arama Davranışını Etkileyen Faktörlerin Araştırılması. Bağımlılık Dergisi 2004;5:72-76.

62. Lichtenstein E, Lando HA, Nothwehr F. Readiness to quit as a predictor of smoking changes in the Minnesota Heart Health Program. Health Psychol 1994;13:393.

63. DiClemente CC, Prochaska JO. Toward a Comprehensive, Transtheoretical Model of Change: Stages of Change and Addictive Behaviors. In: Miller WR, Heather N, Editos. Treating Addictive Behaviors. New York: Plenum Press; 1998, p.3-24.

64. Uebelacker LA, Bailey G, Herman D, Anderson B, Stein M. Patients' beliefs about medications are associated with stated preference for methadone, buprenorphine, naltrexone, or no medication-assisted therapy following inpatient opioid detoxification. J Subst Abuse Treat 2016; 66:48-53.

65. Wang CY, Zhang K, Zhang M. Dysfunctional attitudes, learned helplessness, and coping styles among men with substance use disorders. Soc Behav Pers 2017;45:269280.

66. Eng PA. Piercing the Veil of Learned Helplessness: An Integrated Transpersonal Model of Addiction Doctoral dissertation. CA: California Institute of Integral Studies San Francisco; 2016.

67. Reece AS. Psychosocial and treatment correlates of opiate free success in a clinical review of a naltrexone implant program. Subst Abuse Treat Prev Policy 2007;2:35.

68. Kaziasty K. Soscial support and traumatic stres. The National Center for PostTraumatic Stress Disorder. Res Q 2005;16:1-8.

69. Anlauf M, Hein L, Hense HW, Köbberling J, Lasek R, Leidl R, et al. Complementary and alternative drug therapy versus science-oriented medicine. Ger Med Sci 2015;13:Doc05.

70. Onat Y, Nurmedov S, Noyan C, Darcın A, Dilbaz N, Tarhan K. When is the appropriate time for families to be involved in addiction treatment; from the beginning? A retrospective evaluation of inpatients in a private hospital. J Neurobehav Sci 2015;1:1-5.

71. Stevens A, Berto D, Frick U, Hunt N, Kerschl V, McSweeney T, et al. The relationship between legal status, perceived pressure and motivation in treatment for drug dependence: results from a European study of quasi-compulsory treatment. Eur Addict Res 2006;12:197-209.

72. Yüncü Z, Aydin R, Aydin C, Özbaran B, Köse S. Aile Desteği ya da Denetimli Serbestlik Kararı Sonucu Tedavi Merkezine Başvuran Madde Kullanım Bozukluğu olan Ergenlerin Klinik, Sosyodemografik Farklılıklarının Belirlenmesi ve Denetimli Serbestlik Olgularında Ayıklığı Sağlamada Öngörücü Faktörlerin Belirlenmesi, Nöro-Psikyatri Arșivi 2016;53:130-135.

73. Akdağ EM, Kotan VO, Köse S, Tikır B, Aydemir MÇ, Okay İT, et al. The relationship between internalized stigma and treatment motivation, perceived social support, depression and anxiety levels in opioid use disorder. Psychiatr Clin Psychopharmacol 2018;28:394-401.

74. Akbaş GE, Mutlu E. Madde bağımllilı̆ı tedavisi gören kişilerin bağımlılık ve tedavi deneyimleri. Toplum ve Sosyal Hizmet 2016;27:101-122.

75. Donovan DM. Assessment to Aid in the Treatment Planning Process. In: Allen JP, Wilson VB, Editors. Assessing Alcohol Problems: A Guide for Clinicians and Researchers. Fischers Lane: Bethesda; 2003. 